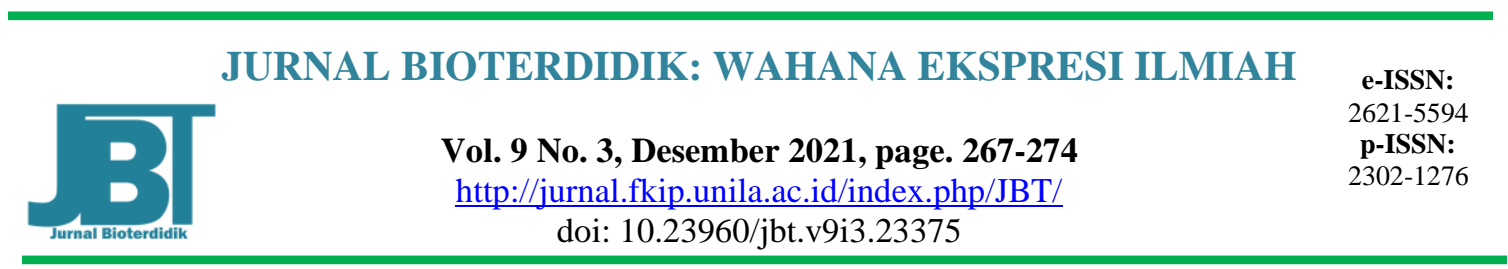

\title{
Pengaruh Strategi Pembelajaran STAD Dengan Bantuan Media Roda Putar Terhadap Hasil Belajar Sistem Ekskresi Manusia
}

\author{
Nelisa Lorenza*, Kartika Manalu, Khairuddin \\ Pendidikan Biologi, Universitas Islam Negeri Sumatera Utara, Indonesia \\ "email: nelisalorenza99@gmail.com
}

Abstract: The Effect of Student Team Achievement Division (STAD) Learning Strategies with Spin Wheel Media on Learning Outcomes of System Human Excretion. This study aims to see the effect of STAD learning strategy on Student Learning Outcomes in the Human Expression System Material in Class VIII MTs TPI Bandar Betsy. This type of research is a Quasi-Experimental Research. The population in this study were all students of class VIII MTs TPI Bandar Betsy consisting of class VIII which was placed 20 students as the experimental class and class VIII B which was designed by 20 students as the control class. The instrument used to collect data was a multiple-choice test consisting of 20 questions. In the research, the data analysis used paired simple t test with the help of SPSS version 22 software. It shows that sig $<0.05$ with a sig value of 0.00 $<0.05$ with a t-count value of 51.822 and a $t$-table of 2.09 in the experimental class. HO is rejected and Ha is accepted. Then it can be revealed that there is an effect of STAD learning strategy with the help of rotating media on student learning outcomes in the human excretion system in class VIII MTs TPI Bandar Betsy.

Keywords: learning outcomes, learning strategy, rotating wheel media, STAD

\begin{abstract}
Abstrak: Pengaruh Strategi Pembelajaran STAD Dengan Bantuan Media Roda Putar Terhadap Hasil Belajar Materi Sistem Ekskresi Manusia. Penelitian ini bertujuan untuk mengetahui pengaruh strategi pembelajaran STAD Terhadap Hasil Belajar Siswa Pada Materi Sistem Eksresi Manusia Di Kelas VIII MTs TPI Bandar Betsy. Jenis penelitian ini adalah penelitian Quasi Eksperimental populasi dalam penelitian ini adalah seluruh siswa kelas VIII MTs TPI Bandar Betsy yang terdiri dari kelas VIII A yang berjumlah 20 siswa sebagai kelas eksperimen dan kelas VIII B berjumlah 20 siswa sebagai kelas kontrol. Instrument yang digunakan untuk menggumpulkan data adalah tes berbentuk pilihan ganda yang terdiri dari 20 soal. Pada penelitian ini analisis data menggunakan uji uji paired simple $t$ test dengan bantuan software SPSS versi 22. menunjukan bahwa sig $<0,05$ dengan nilai sig $0,00<0,05$ dengan nilai t-hitung 51,822 dan t-tabel 2,09 pada kelas eksperimen H0 ditolak dan Ha diterima. Maka dapat disimpulkan bahwa ada pengaruh strategi pembelajaran STAD dengan bantuan media roda putar terhadap hasil belajar siswa pada materi sistem ekskresi manusia di kelas VIII MTs TPI Bandar Betsy.
\end{abstract}

Kata kunci: hasil belajar, media roda putar, STAD, strategi pembelajaran 


\section{PENDAHULUHAN}

Proses pembelajaran yang efektif di sekolah harus didukung oleh pengembangan metode pembelajaran yang mampu diterapkan kepada peserta didik di dalam proses pembelajaran. Metode pembelajaran yang efektif didasarkan pada sejauh mana dalam proses pembelajaran guru dapat membuat peserta didik aktif dalam proses pembelajaran. Maka dari itu metode adalah faktor terpenting dalam menciptakan proses pembelajaran yang efektif.

Berdasarkan hasil observasi yang telah peneliti lakukan di sekolah MTs TPI Bandar Betsy pada tanggal 6 januari 2021 diperoleh data bahwa pada saat proses kegiatan pembelajaran materi biologi pada mata pelajaran IPA, siswa kurang aktif dalam mengikuti pembelajaran atau sulit memahami materi yang dijelaskan oleh guru sehingga rata-rata hasil belajar siswa kelas VIII MTs TPI Bandar Betsy dalam mata pelajaran IPA masih rendah yaitu dibawah nilai KKM. Dimana nilai KMM mata pelajaran IPA adalah 72 dan nilai yang didapat siswa pada pelajaran IPA masih banyak yang tidak mencapai KKM. Pada mata pelajaran IPA siswa yang mendapat nilai di bawah KKM sebanyak 58\% dari jumlah siswa dengan rata-rata nilai siswa 60. Hal ini menunjukan hasil belajar siswa pada mata pelajaran IPA masih rendah.

Berdasarkan hasil wawancara yang Peneliti lakukan dengan guru mata pelajaran IPA di kelas VIII MTs TPI Bandar betsy dapat diketahui bahwa strategi pembelajaran yang diterapkan oleh guru mata pelajaran IPA di kelas cenderung hanya berjalan satu arah, dimana guru yang lebih banyak aktif memberikan informas pembelajaran kepada siswa. Oleh karena itu diperlukan strategi pembelajaran yang tepat untuk dapat menciptakan proses pembelajaran yang menyenangkan dan mampu meningkatkan keaktifan siswa selama proses pembelajaran. Salah satu strategi pembelajaran yang lebih aktif dan menyenangkan adalah strategi Student Team Achievement Division (STAD).

Strategi pembelajaran STAD merupakan salah satu tipe kooperatif yang menekankan pada adanya aktivitas dan interaksi di antara siswa untuk saling memotivasi dan saling membantu dalam menguasai materi pelajaran guna mencapai prestasi yang maksimal. Pada proses pembelajaran selain menggunakan strategi pembelajaran media juga dapat digunakan sebagai alat bantu dalam proses pembelajaran. Media pembelajaran adalah Segala sesuatu yang dapat digunakan untuk merangsang pikiran, perasaan, perhatian dan kemampuan atau keterampilan pembelajaran sehingga dapat mendorong terjadinya proses belajar. Media pembelajaran digunakan sesuai dengan kebutuhan dan materi apa yang diajarkan, selain itu juga harus memperhatikan kesanggupan guru dalam menggunakannya. Media merupakan salah satu faktor penting dalam peningkatan kualitas pembelajaran.

Media roda putar adalah media pembelajaran yang dibuat dalam suatu permainan dengan cara memutar roda yang bernomor. Permainan diharuskan untuk memutar roda bernomor dan roda akan berhenti di salah satu petak dari bagian nomor. Setiap berhenti disalah satu petak dari bagian nomor, pemain atau siswa harus siap menjawab pertanyaan yang telah disediakan di setiap papan bernomor tersebut. Materi sistem ekskresi banyak memuat tentang organ-organ dan proses pengeluaran sisa metabolisme yang tidak berguna lagi yang terjadi pada tubuh manusia. Masalah yang sering terjadi pada saat proses pembelajaran sistem ekskresi yaitu siswa sulit memahami materi dan siswa merasa bosan. Maka pada materi sistem ekskresi strategi yang digunakan harus menarik sehingga materi dapat dipahami dengan baik. Pada strategi STAD sesuai untuk materi-materi ilmu pengetahuan ilmiah, seperti materi IPA di MTs atau SMP. Strategi STAD berguna memotivasi hasil belajar peserta didik untuk saling mendukung dan membantu satu sama 
lain dalam menguasai pengetahuan yang diberikan oleh guru. Meskipun para peserta didik saling membantu, tetapi pada saat mengerjakan kuis peserta didik tidak diperbolehkan saling membantu.

\section{METODE}

Penelitian dilakukan di MTs TPI Bandar Betsy Kecamatan Bandar Huluan Kabupaten Simalungun. Waktu penelitian dilakukan pada pembelajaran semester genap tahun ajaran 2020/2021 tepatnya pada bulan Januari 2021 sampai pada bulan Febuari 2021. Populasi dalam penelitian ini adalah seluruh peserta didik kelas VIII MTs TPI Bandar Betsy, sebanyak 2 kelas.

Teknik sampling yang digunakan dalam penelitian ini adalah Non Probability Sampling adalah populasi dipilih tanpa mengetahui peluang pemilihnya. Dalam Non Probability Sampling yang dipilih adalah jenis sampling jenuh yaitu teknik penentuan menggunakan seluruh anggota yang dijadikan sabagai sampel. Sampel yang diambil dalam penelitian ini terdiri dari dua kelas yaitu kelas VIII A yang terdiri dari 20 siswa dan dibagi menjadi 5 kelompok sebagai kelas Eksperimen yang diterapkan strategi pembelajaran STAD dengan bantuan media roda putar dan kelas VIII B terdiri dari 20 siswa sebagai kelas kontrol yang diterapkan strategi konvensional.

Data dalam penelitian ini diperoleh dari hasil belajar peserta didik pada materi sistem ekskresi manusia. Teknik pengumpulan data yang digunakan adalah teknik tes dalam bentuk objektif. Tes yang digunakan berupa pre-tes dan post-tes dengan 20 soal dalam bentuk tes objektif dengan (pilihan berganda) yang mempunyai option a, b, c, dan $\mathrm{d}$ tentang materi sistem ekskresi pada manusia. Tes ini diberikan pada kelas eksperimen dan kelas kontrol.

\section{HASIL DAN PEMBAHASAN}

Penelitian ini bertujuan untuk melihat hasil belajar siswa dengan menggunakan strategi STAD dengan bantuan media roda putar, yang dilakukan dengan menggunakan pretest dan posttest pada kelas eksperimen dan kelas kontrol. Berdasarkan Tabel 1 diketahui bahwa nilai rata-rata pretest STAD dengan bantuan media roda putar adalah 28,00 sedangkan pretest Konvensional nilai rata-ratanya adalah 25,00. Hasil posttest STAD dengan media roda putar rata-ratanya adalah 81,50, sedangkan pada Konvensional rata-ratanya adalah 61,75 .

Tabel 1. Deskripsi Hasil Pre Test dan Post Test Siswa

\begin{tabular}{lcccccc}
\hline \multicolumn{1}{c}{ Hasil Belajar } & N & Minimum & Maksimum & Rata-rata & $\begin{array}{c}\text { Standar } \\
\text { Deviansi }\end{array}$ & Varian \\
\hline $\begin{array}{l}\text { Pretest } \\
\text { (STAD dengan media roda putar) }\end{array}$ & 20 & 10 & 45 & 28,00 & 9,375 & 87,895 \\
\hline $\begin{array}{l}\text { Posttest } \\
\text { (STAD dengan media roda putar) }\end{array}$ & 20 & 55 & 95 & 81,50 & 9,611 & 92,368 \\
\hline $\begin{array}{l}\text { Pretest (Konvensional) } \\
\text { Posttest (Konvensional) }\end{array}$ & 20 & 10 & 40 & 25,00 & 8,885 & 78,947 \\
\hline
\end{tabular}


Berdasarkan data yang dibuat pada tabel dapat dibuat histogram perbandingan ratarata nilai pretest dan posttest hasil belajar kelas eksperimen dan kelas kontrol seperti pada Gambar 1.

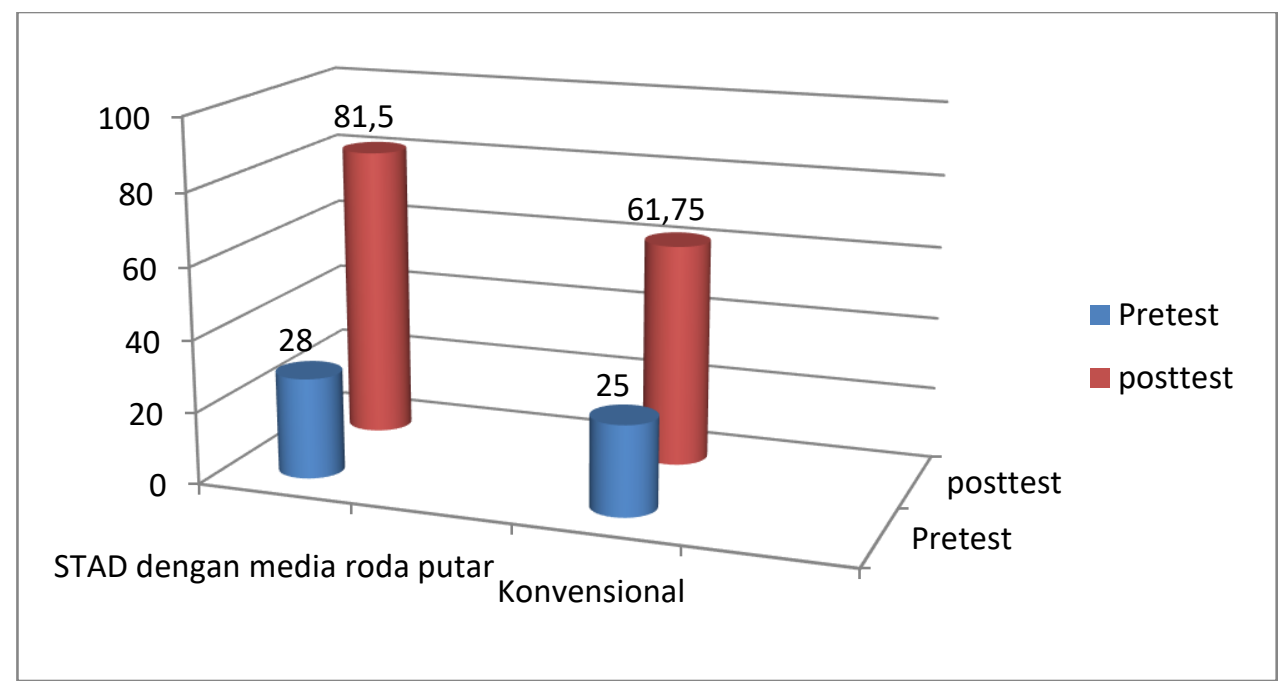

Gambar 1. Rata-Rata Nilai Pretest dan Posttest

Berdasarkan Gambar 1 dapat diketahui bahwa kelas yang diperlakukan dengan strategi pembelajaran STAD dengan bantuan media roda putar dan kelas yang diperlakukan dengan strategi pembelajaran konvensional mengalami peningkatan dari nilai pretest dan posttest. Dari histogram diatas hasil belajar kelas dengan strategi pembelajaran STAD dengan bantuan media roda putar lebih tinggi dibandingkan dengan strategi pembelajaran konvensional.

Tabel 2. Hasil Uji Normalitas Hasil Belajar Siswa

\begin{tabular}{|c|c|c|c|c|c|}
\hline \multicolumn{6}{|c|}{ One-Sample Kolmogorov-Smirnov Test } \\
\hline & & $\begin{array}{c}\text { Pretest } \\
\text { STAD } \\
\text { dengan } \\
\text { media roda } \\
\text { putar }\end{array}$ & $\begin{array}{c}\text { Posttest } \\
\text { STAD } \\
\text { dengan } \\
\text { media roda } \\
\text { putar }\end{array}$ & $\begin{array}{c}\text { Pretest } \\
\text { Konvensional }\end{array}$ & $\begin{array}{c}\text { Posttest } \\
\text { Konvensional }\end{array}$ \\
\hline $\mathrm{N}$ & & 20 & 20 & 20 & 20 \\
\hline \multirow[t]{2}{*}{ Normal Parameters ${ }^{\mathrm{a}, \mathrm{b}}$} & Mean & 28.00 & 81.50 & 25.00 & 61.75 \\
\hline & $\begin{array}{l}\text { Std. } \\
\text { Deviation }\end{array}$ & 9.375 & 9.611 & 8.885 & 11.951 \\
\hline \multirow{3}{*}{$\begin{array}{l}\text { Most Extreme } \\
\text { Differences }\end{array}$} & Absolute & .134 & .192 & .113 & .143 \\
\hline & Positive & .103 & .108 & .113 & .143 \\
\hline & Negative & -.134 & -.192 & -.113 & -.142 \\
\hline \multicolumn{2}{|l|}{ Test Statistic } & .134 & .192 & .113 & .143 \\
\hline \multicolumn{2}{|l|}{ Asymp. Sig. (2-tailed) } & $200^{\mathrm{c}, \mathrm{d}}$ & $.051^{\mathrm{c}}$ & $.200^{\mathrm{c}, \mathrm{d}}$ & $.200^{\mathrm{c}, \mathrm{d}}$ \\
\hline \multicolumn{6}{|c|}{ a. Test distribution is Normal. } \\
\hline \multicolumn{6}{|c|}{ b. Calculated from data. } \\
\hline \multicolumn{6}{|c|}{ c. Lilliefors Significance Correction. } \\
\hline
\end{tabular}


Uji Persyaratan Analisis. Pada penelitian ini, uji normalitas dilakukan uji One Sample Kolmogorov Smirnov Test dengan menggunakan bantuan program software Statistical Product and Service Solution (SPSS) versi 22. Dalam uji normalitas terdapat kreteria signifikasi, jika signifikasi kurang dari 0,05 maka data yang diperoleh tidak berdistribusi normal, dan jika signifikasi lebih dari 0,05 maka data yang diperoleh berdistribusi normal. Hasil normalitas hasil belajar siswa dapat dilihat pada Tabel 2.

Berdasarkan Tabel 2 dapat dilihat bahwa hasil pretest dan posttest hasil belajar siswa pada kelas yang diperlakukan dengan strategi pembelajaran STAD dengan bantuan media roda putar dan kelas yang diperlakukan dengan strategi Konvensional berdistribusi normal. Dengan nilai sig 0,20>0,05 (hasil pretest strategi STAD dengan bantuan media roda putar), sig 0,051>0,050 (posttest strategi STAD dengan bantuan media roda putar), sig 0,20>0,050 (pretest strategi Konvensional), sig 0,20>0,050 (posttest strategi Konvensional).

Uji Homogenitas. Pada penelitian ini uji homogenitas menggunakan bantuan program software Statistical Product and Service Solution (SPSS) versi 22. Dalam uji homogenitas kriteria uji ini dengan melihat signifikasi > 0,05 maka data dikatakan homogen. Hasil uji homogenitas hasil belajar siswa dapat dilihat pada Tabel 3. Berdasarkan hasil uji homogenitas hasil belajar siswa pada tabel 3 di atas menunjukan bahwa signifikasi 0,37 > 0,05 yang berarti sampel berasal dari populasi yang variansinya homogen.

Tabel 3. Uji Homogenitas Hasil Belajar Siswa

\begin{tabular}{llrrrr}
\hline & \multicolumn{1}{c}{ Test of Homogeneity of Variance } & & & \\
\hline & Levene Statistic & df1 & df2 & \multicolumn{1}{c}{ Sig. } \\
\hline Hasil Belajar & Based on Mean & .818 & 1 & 38 & .371 \\
\cline { 2 - 7 } & Based on Median & .946 & 1 & 38 & .337 \\
\cline { 2 - 6 } & $\begin{array}{l}\text { Based on Median and with } \\
\text { adjusted df }\end{array}$ & .946 & 1 & 38.000 & .337 \\
\cline { 2 - 6 } & \begin{tabular}{l} 
Based on trimmed mean \\
\cline { 2 - 6 }
\end{tabular} & .865 & 1 & 38 & .358 \\
\hline
\end{tabular}

Uji Hipotesis. Pada uji hipotesis penelitian ini menggunakan uji t. uji t digunakan untuk mengetahui adanya pengaruh strategi pembelajaran STAD dengan bantuan media roda putar terhadap hasil belajar siswa. Uji hipotesis diuji menggunakan bantuan software SPSS versi 22. Ketentuan kriteria adalah jika nilai sig (2-tailed) $<0,05$ maka terdapat pengaruh yang signifikan. Maka jika nilai sig (2-tailed) $>0,50$ maka tidak terdapat pengaruh yang signifikan. Hasil uji hipotesis hasil belajar siswa dapat dilihat pada Tabel 4. Berdasarkan Tabel 4 dapat dilihat hasil analisis uji paired samples test menunjukan bahwa sig $<0,05$ dengan nilai sig $0,00<0,05$ dengan nilai t-hitung 51,822 dan t-tabel 2,09 pada strategi pembelajaran STAD dengan bantuan media roda putar sehingga H0 ditolak dan $\mathrm{Ha}$ diterima. Maka dapat disimpulkan bahwa ada pengaruh strategi pembelajaran STAD dengan bantuan media roda putar terhadap hasil belajar siswa pada materi sistem ekskresi manusia di kelas VIII MTs TPI Bandar Betsy. 
Tabel 4. Uji Hipotesis Hasil Belajar Siswa

\begin{tabular}{|c|c|c|c|c|c|c|c|c|c|}
\hline \multicolumn{10}{|c|}{ Paired Samples Test } \\
\hline & & \multicolumn{5}{|c|}{ Paired Differences } & \multirow[b]{3}{*}{$\mathrm{t}$} & \multirow[b]{3}{*}{$\mathrm{df}$} & \multirow{3}{*}{$\begin{array}{l}\text { Sig. } \\
(2- \\
\text { tailed })\end{array}$} \\
\hline & & \multirow[b]{2}{*}{ Mean } & \multirow{2}{*}{$\begin{array}{c}\text { Std. } \\
\text { Deviation }\end{array}$} & \multirow{2}{*}{$\begin{array}{l}\text { Std. } \\
\text { Error } \\
\text { Mean }\end{array}$} & \multicolumn{2}{|c|}{$\begin{array}{l}\text { 95\% Confidence } \\
\text { Interval of the } \\
\text { Difference }\end{array}$} & & & \\
\hline & & & & & Lower & Upper & & & \\
\hline $\begin{array}{l}\text { Pair } \\
1\end{array}$ & $\begin{array}{l}\text { Pretest } \\
\text { STAD dengan media roda } \\
\text { putar Posttest STAD dengan } \\
\text { media roda putar }\end{array}$ & $53.500^{-}$ & 4.617 & 1.032 & $55.661^{-}$ & -51.339 & $51.822^{-}$ & 19 & .000 \\
\hline $\begin{array}{l}\text { Pair } \\
2\end{array}$ & $\begin{array}{l}\text { Pretest Konvensional } \\
\text { Posttest Konvensional }\end{array}$ & $\begin{array}{r}- \\
36.750\end{array}$ & 4.667 & 1.043 & $\begin{array}{r}- \\
38.934\end{array}$ & -34.566 & 35.219 & 19 & .000 \\
\hline
\end{tabular}

Berdasarkan penelitian yang dilakukan analisis data diperoleh bahwa data yang digunakan berdistribusi normal, dan sampel rata-rata bersifat homogen. Dari hasil penelitian yang dilakukan bahwa hasil belajar siswa mengalami peningkatan baik dikelas eksperimen maupun kelas kontrol, tetapi pada kelas eksperimen hasil belajar siswa lebih tinggi mengalami peningkatan hasil belajar dibandingkan pada kelas kontrol. Berdasarkan pernyataan yang ada di atas, data bersifat normal dan homogen, maka dapat dilakukan uji hipotesis yang menggunakan uji t dengan bantuan software SPSS versi 22.

Pengujian hipotesis diperoleh bahwa hipotesis penelitian (Ha) diterima dan (Ho) di tolak. Pada penelitian ini sig $<0,05$ dengan nilai sig $0,00<0,05$ dengan nilai t-hitung 51,822 dan t-tabel 2,09 artinya terdapat pengaruh yang signifikan terhadap strategi pembelajaran STAD dengan bantuan media roda putar terhadap hasil belajar siswa.

Hal ini didukung oleh penelitian yang dilakukan Normasintasari, dkk (2018) memaparkan dengan menggunakan strategi STAD berpengaruh terhadap hasil belajar siswa. Huda mengungkapkan bahwa strategi STAD memperkenalkan gagasan tentang waktu tunggu atau berpikir, pada elemen interaksi pembelajaran yang menjadi salah satu faktor ampuh dalam meningkatkan respon siswa terhadap pertanyaan.

Harahap (2017) menyatakan bahwa model pembelajaran STAD mendorong siswa untuk saling membantu satu sama lain jika siswa ingin kelompok mereka memperoleh penghargaan. Sehingga melalui model STAD siswa sangat terbantu untuk memahami materi karena mereka bisa berdiskusi dengan teman lain, siswa juga terlihat lebih aktif untuk bersaing antar kelompok. Berdasarkan penelitian rata-rata nilai kelas eksperimen 66 dan kelas control 32,89 dengan ini maka pembelajaran STAD berpengaruh terhadap hasil belajar biologi siswa kelas XI SMA Negeri 9 Lubuk Linggau. Dengan demikian dalam penelitian ini dapat disimpulkan bahwa terdapat pengaruh pembelajaran STAD dengan bantuan media roda putar pada materi sistem ekskresi manusia terhadap hasil belajar siswa.

\section{SIMPULAN}

Rata-rata hasil belajar siswa yang dibelajarkan dengan STAD dengan bantuan media roda putar lebih tinggi dibandingksn pembelajaran konvensional dan signifikan pada signifikasi 0,05 yang menunjukkan bahwa terdapat pengaruh strategi STAD dengan bantuan media roda putar terhadap hasil belajar. 


\section{DAFTAR RUJUKAN}

Alfianika. (2018). Metode Penelitian Pengajaran Bahasa Indonesia. Yogyakarta: CV. Budi Utama.

Fathonatun, (2016). Pengembangan Permainan Question Whell (Roda Pertanyaan) Sebagai Media Pembelajaran Untuk Melatih Keaktifan Menjawab Dan Meningkatkan Hasil Belajar Siswa Pada Materi Jamur. Jurnal Berkala Ilmiah Pendidikan Biologi, 5(3).

Nasution, I \& Pratiwi. (2017). Profesi Kependidikan. Depok: Prenadamedia Group.

Normasintari, dkk. (2018). Pengaruh Model Pembelajaran Kooperatif Tipe STAD Media Poster Terhadap Hasil Belajar Peserta Didik, Jurnal Ilmiah Sekolah Dasar, 2(2).

Nurlatifah, A \& Septi, A. (2017). Pengaruh Model Pembelajaran Kooperatif Tipe Student Team Achievement Division (STAD) Terhadap Hasil Belajar IPA Ditinjau Dari Keaktifan Siswa. Journal of Education Action Research, 4(2).

Slameto. (2020). Strategi Implementasi Berbasis Sekolah (MBS) Dengan Prpfesional, Yogyakarta: CV. Penerbit Qiara Media.

Taniredja, et. al. (2017). Model-model Pembelajaran Inovatif dan Efektif, Bandung: Alfabeta.

Widi, W. (2014). Metodologi Pembelajaran IPA. Jakarta: Bumi aksara. 